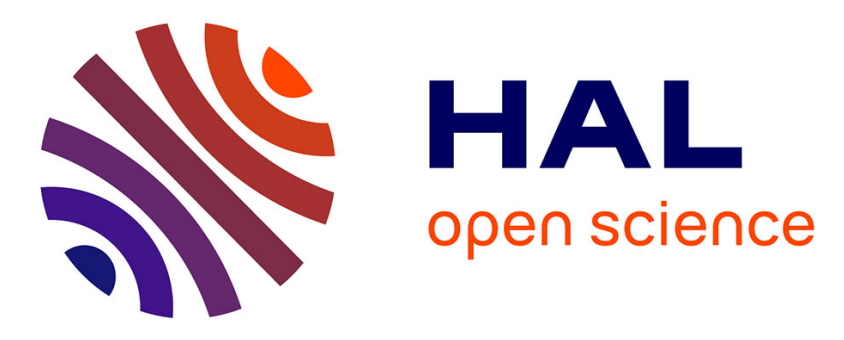

\title{
Continuous biohydrogen production from a food industry waste: Influence of operational parameters and microbial community analysis
}

Maria Alexandropoulou, Georgia Antonopoulou, Eric Trably, Hélène Carrère, Gérasimos Lyberatos

\section{To cite this version:}

Maria Alexandropoulou, Georgia Antonopoulou, Eric Trably, Hélène Carrère, Gérasimos Lyberatos. Continuous biohydrogen production from a food industry waste: Influence of operational parameters and microbial community analysis. Journal of Cleaner Production, 2018, 174, pp.1054-1063. 10.1016/j.jclepro.2017.11.078 . hal-02623402

\section{HAL Id: hal-02623402 \\ https: / hal.inrae.fr/hal-02623402}

Submitted on 26 May 2020

HAL is a multi-disciplinary open access archive for the deposit and dissemination of scientific research documents, whether they are published or not. The documents may come from teaching and research institutions in France or abroad, or from public or private research centers.
L'archive ouverte pluridisciplinaire HAL, est destinée au dépôt et à la diffusion de documents scientifiques de niveau recherche, publiés ou non, émanant des établissements d'enseignement et de recherche français ou étrangers, des laboratoires publics ou privés. 


\section{Accepted Manuscript}

Continuous biohydrogen production from a food industry waste: Influence of operational parameters and microbial community analysis

Maria Alexandropoulou, Georgia Antonopoulou, Eric Trably, Helene Carrere,

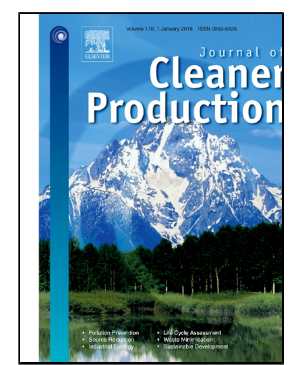
Gerasimos Lyberatos

PII: S0959-6526(17)32738-5

DOI: 10.1016/j.jclepro.2017.11.078

Reference: JCLP 11217

To appear in: Journal of Cleaner Production

Received Date: 05 March 2017

Revised Date: 24 October 2017

Accepted Date:

11 November 2017

Please cite this article as: Maria Alexandropoulou, Georgia Antonopoulou, Eric Trably, Helene Carrere, Gerasimos Lyberatos, Continuous biohydrogen production from a food industry waste: Influence of operational parameters and microbial community analysis, Journal of Cleaner Production (2017), doi: 10.1016/j.jclepro.2017.11.078

This is a PDF file of an unedited manuscript that has been accepted for publication. As a service to our customers we are providing this early version of the manuscript. The manuscript will undergo copyediting, typesetting, and review of the resulting proof before it is published in its final form. Please note that during the production process errors may be discovered which could affect the content, and all legal disclaimers that apply to the journal pertain. 
4 Maria Alexandropoulou ${ }^{1,2}$, Georgia Antonopoulou, ${ }^{1, *}$, Eric Trably ${ }^{3}$, Helene Carrere ${ }^{3}$, Gerasimos 5 6

17 Abstract

18 The objective of this study was to assess the influence of the hydraulic retention time (HRT) and

\section{Continuous biohydrogen production from a food industry waste:}

\section{Influence of operational parameters and microbial community analysis}

Lyberatos $^{1,2}$,

${ }^{1}$ Institute of Chemical Engineering Sciences (FORTH/ICE-HT), Stadiou, Platani, Patras, 26504, Greece

${ }^{2}$ School of Chemical Engineering, National Technical University of Athens, GR 15780 Athens, Greece

${ }^{3}$ LBE, INRA, 11100, Narbonne, France
*Corresponding author: geogant@,chemeng.upatras.gr; tel: +302610965318, fax:

$$
+302610965318
$$

the $\mathrm{pH}$ on the fermentative hydrogen production from a food industry waste (FIW), in a continuous stirred tank bioreactor. Thus, hydrogen production was investigated for HRTs of 12 ,

8,6 and $4 \mathrm{~h}$ and the results showed a long and stable reactor operation with high hydrogen

22 content in the gas phase and high hydrogen production rates. The optimal HRT was found to be in the range between 6 and $12 \mathrm{~h}$, corresponding to hydrogen yields of $96.27 \pm 3.36$ and $101.75 \pm$ 
$13.71 \mathrm{~L} \mathrm{H}_{2} / \mathrm{kg} \mathrm{FIW}$ for 12 and $6 \mathrm{~h}$, respectively. In the sequel, the effect of the $\mathrm{pH}$ (in the range 5

2 - 5.9) was investigated, by changing the buffer solution (BS) components, while the HRT value

3 was maintained at $12 \mathrm{~h}$. As anticipated, the results showed that the operating $\mathrm{pH}$ had a significant

4 influence on hydrogen production rates and yields. Characterization of the microbial community

5 was performed at various $\mathrm{pH}$ values, giving thus a deeper insight to the well-established

6 hydrogen production process from FIW, since the possible biochemical pathways followed by

7 the microbial consortium, under different operational conditions were elucidated.

8

9 Keywords: Food industry waste, fermentative hydrogen production, hydraulic retention time,

$10 \mathrm{pH}$ effect, microbial community analysis, continuous fermentation

11

12 
2 Environmental pollution, as well as the greenhouse effect caused by the use of conventional

3 fuels, make necessary to find clean and efficient alternative energy sources. Hydrogen $\left(\mathrm{H}_{2}\right)$ has

4 been widely recognized as an alternative to fossil fuels and a source for chemicals and fuels

5 synthesis, due to its high energy content $(142 \mathrm{MJ} / \mathrm{kg})$ and zero carbon emissions when burnt

6 (Moreno-Andrade et al., 2015; Muri et al., 2016). Among various production processes,

7 biological hydrogen production methods are less energy intensive, and occur at ambient

8 temperatures and pressures. These methods include water biophotolysis, photofermentation and

9 dark fermentation (Ntaikou et al., 2010). Among them, dark fermentation (DF) from organic solid waste such as food waste (FW) is the most promising and eco-friendly approach (Castillo-

11 Hernandez et al., 2015). DF has received an increasing attention, due to its advantages, such as

12 the flexibility of operation under different temperature and pressure conditions, the high

13 production rates and the possibility to use renewable feedstocks as substrates (Ghimire et al., $14 \quad 2015 a)$.

15 According to Girotto et al. (2015), FW is defined as the material initially intended for human 16 consumption that is lost, degraded, contaminated or discharged as surplus, and that cannot be 17 subsequently used as food. FW has two main sources; plants (i.e. cereals, potato, oil crops, citrus etc.) or animals (i.e. meat by-products, cheese whey etc.) (Galanakis, 2012). Currently, $1.310^{9}$

19 tonnes of food, corresponding to one third of the globally produced food, are disposed to landfill

20 sites as waste. This is not a desirable option either from an environmental or from an economic 21 point of view (Dung et al., 2014; Thi et al., 2016) since when FW is buried in landfill sites, most

22 of its energy content is lost (Melikoglu et al., 2013). Furthermore, this practice of disposing FW

23 to landfills creates many problems in public life and health, such as bad odor, air pollution and 24 leaching. 
1 Alternatively, FW derived from agricultural production, households, restaurants or food

2 processing industries could be a promising raw material for biofuels' or bio-based products

3 generation, due to its high organic content and availability. Depending on the specific

4 characteristics of the FW used, different biotechnological fermentative processes could be

5 proposed. Thus, FW rich in carbohydrates is typically used for bioethanol (Matsakas et al., 2014)

6 or fermentative hydrogen production, either in batch or continuous systems (Thi et al., 2016).

7 During fermentation for hydrogen production, fermentative bacteria hydrolyse and ferment

8 complex polymers to Volatile Fatty Acids (VFAs), which, depending on the particular type, are

9 accompanied or not by the production of hydrogen which is transferred to the gas phase (Han et

10 al., 2015). Hence, in order to achieve effective anaerobic fermentative hydrogen production,

11 understanding the microbial populations that are responsible for hydrogen production and the

12 role of co-existing non-hydrogen-producing microorganisms, is imperative (Karthic et al., 2013).

13 A variety of factors has been found to significantly affect dark fermentative hydrogen production

14 and its yields in continuous systems. Thus, a stable, long-term continuous dark fermentation

15 strongly depends on the prevailing environmental and/or operating conditions, such as the $\mathrm{pH}$,

16 the Hydraulic Retention Time (HRT), the substrate concentration, the operational temperature,

17 the start-up of the reactor and the inoculum type (Antonopoulou et al., 2010). These factors also

18 influence the microbial communities, which are responsible for the selection of biochemical

19 pathways and consequently for final hydrogen yields and end-products distribution ( $\mathrm{Li}$ and Fang,

20 2007; Antonopoulou et al., 2010).

21 During the last decade, extensive experimental research has been carried out to determine the

22 optimal operational conditions for maximizing the hydrogen production rates and yields. The $\mathrm{pH}$

23 of the culture medium is a crucial factor that strongly influences either the activities of hydrogen 
1 producing bacteria, via the hydrogenase enzymes, or the selection of metabolic pathways and

2 consequently the final VFAs speciation (Cubillos et al., 2010). Thus, in the case that the $\mathrm{pH}$ is

3

4 not maintained within an optimal range, hydrogen production may be inhibited or even cease due to a microbial population shift, indicating that the control of $\mathrm{pH}$ during continuous hydrogen production experiments is an imperative need. A wide range of optimal $\mathrm{pH}$ values has been reported to enhance hydrogen yields, when using FW as substrate. Sattar et al. (2016) reported an initial $\mathrm{pH}$ equal to 7 as optimal for batch mesophilic $\left(37^{\circ} \mathrm{C}\right)$ hydrogen production of $\mathrm{FW}$, codigested with mixed consortia of Clostridium sp., while Wongthanate and Chinnacotpong (2015) found that an initial $\mathrm{pH}$ of 8 led to maximum hydrogen production in batch reactors, using FW collected from a university cafeteria. Cappai et al. (2014) who investigated DF of synthetic FW found that the optimal $\mathrm{pH}$ value was 6.5. A similar conclusion was reached by Wongthanate et al. (2014) who studied mesophilic biohydrogen production from coconut milk. In the case of continuous operation, the addition of external alkalinity sources such as alkali $(\mathrm{NaOH})$ or buffer solutions (bicarbonate or phosphate) is commonly reported in order to maintain the culture $\mathrm{pH}$ within designated levels (Zhao and Yu, 2008; Antonopoulou et al., 2010). For example, Ghimire et al. (2015a) who studied biohydrogen production from FW in a semi-continuous process, added $\mathrm{NaOH}(1 \mathrm{M})$ to the feed medium, in order to adjust its $\mathrm{pH}$ to 7.0. Furthermore, Kim and Lee, (2010), who studied continuous hydrogen production in a continuous stirred tank reactor (CSTR) from tofu-processing waste at a $\mathrm{pH}$ range between $5.0-6.0$, obtained maximum hydrogen production rate and yield when the $\mathrm{pH}$ was 5.5. Consistently, Lee et al. (2010), who studied DF of high-solid FW in a semi-continuous reactor, obtained maximum hydrogen yield when the $\mathrm{pH}$ was approximately 5.5 . 
1 The HRT is also a factor of great importance for achieving a stable and efficient hydrogen

2 production process. The HRT is defined as the mean time for a defined volume element of

3 substrate to pass through all stages of a reactor system before being discharged. This is the

4 average length of time during which the substrate interacts with the microbes in the reactor to

5 achieve the required conversion (Arimi et al., 2015). The HRT affects fermentative metabolism

6 as well as microbial composition and activity. It has been reported that short HRTs (between a

7 few hours and one day) promote hydrogen production and can be used to wash out methanogenic

8 microorganisms in fermentative reactors (Moreno-Andrade et al., 2015; Arimi et al., 2015). In

9 this line, continuous DF of FW has been studied under different HRT values, in order to find the

10 optimum. In particular, Moreno-Andrade et al. (2015) who investigated DF of FW in an

11 anaerobic sequencing batch reactor (ASBR) at HRT values from 6 to $72 \mathrm{~h}$, found that the

12 maximum volumetric hydrogen production was achieved for an HRT value of $24 \mathrm{~h}$, while the

13 maximum hydrogen yield (103.6 $\pm 19.8 \mathrm{~mL} \mathrm{H}_{2} / \mathrm{g}$ COD removed) was achieved for an HRT of

$1412 \mathrm{~h}$. Lee et al. (2010) studied DF of high-solid FW in a semi-continuous reactor and the

15 maximum hydrogen yield was obtained when the HRT was $1.9 \mathrm{~d}$. Alexandropoulou et al. (2016)

16 who investigated fermentative hydrogen production of the diluted soluble fraction of FIW (after

17 an extraction process) using an Up-Flow Column Reactor (UFCR) at HRTs in the range of 2-12

$18 \mathrm{~h}$, found that the hydrogen yields were maximized at an HRT of $12 \mathrm{~h}$. Based on the literature, the

19 majority of studies concerning fermentative hydrogen production, presents the influence of only

20 one operational parameter on hydrogen production rates and yields.

21 The aim of the present study was to assess for the first time the influence of HRT and $\mathrm{pH}$ value

22 on continuous fermentative hydrogen production, using a suspension of a food industry waste

23 (FIW) as substrate and a CSTR-type bioreactor. Among the main objectives was to establish a 
1 long term, stable operation of continuous fermentative hydrogen production, at different

2 operational parameters i.e. various HRT and $\mathrm{pH}$ values, using a mixed microbial culture at

3 mesophilic conditions, coming from the indigenous microbial consortium of FIW. By varying

4 the HRT and the culture $\mathrm{pH}$ over a wide range of values, the optimum operational conditions for

5 hydrogen production and VFAs distribution were determined. Each parameter was studied

6 individually so as to assess its individual role on hydrogen yields, hydrogen production rates, and

7 metabolic products distribution. In the case of the experiment where the $\mathrm{pH}$ effect was

8 investigated, the microbial community was analyzed and correlated with reactor performances

9 and metabolic end-product distribution, giving thus a deeper insight in the well-established

10 hydrogen production process.

11

\section{Materials and methods}

\subsection{Food industry waste (FIW)}

FIW was provided from a particular food company, located in Athens, Greece. It was composed of expired solid baby foods (out-of-date products) in seven different flavours (in the form of a powder), which were returned from the market to the company. The mixture of seven solid baby foods was rich in carbohydrates rendering it a suitable feedstock for fermentative hydrogen production. For the preparation of the feed, the seven food products were homogenized and then suspended in deionized water (suspended food industry waste: SFIW) and supplemented with nutrients, so that the final concentration of the carbohydrates and chemical oxygen demand (COD) were as presented in table 1 . The feeding medium preparation conditions were selected based on preliminary batch experiments, where it was found that an initial concentration of carbohydrates of approximately $12.5 \mathrm{~g} / \mathrm{L}$ was the optimum among the concentration range that was tested $(2.5-25$

$$
\text { g/L) (data not shown). }
$$


2 Two different experimental series were carried out in order to investigate the HRT as well as the

3 culture $\mathrm{pH}$ effect, on continuous fermentative hydrogen production from SFIW, using the FIW

4 also as inoculum. The hydrogen producing reactor was a double-walled stainless steel, cylindrical

5 CSTR-type reactor with a working volume of $0.4 \mathrm{~L}$, operated under mesophilic conditions $\left(35^{\circ} \mathrm{C}\right)$.

6 From preliminary batch experiments, it was shown that the indigenous microbial consortium of the

7 FIW was not so active under thermophilic conditions (data are not shown) and thus the

8 temperature of $35^{\circ} \mathrm{C}$ was selected as operational condition in this study. Temperature control was

9 achieved via recirculation of water in the outer jacket. The reactor was fed intermittently, every 3

$10 \mathrm{~h}$, via a peristaltic pump with the SFIW, maintained at a temperature below $4^{\circ} \mathrm{C}$, with a flow rate

11 appropriate in order to achieve the desirable HRT value. The reactor was mechanically stirred with

12 a propeller periodically for $15 \mathrm{~min}$, twice per hour. Feeding was programmed always with the

13 stirring on. Simultaneous flow of the effluent occurred during feeding by liquid overflow, in order

14 to maintain constant reactor volume. As a result, a portion of the feed was removed with the

15 effluent and the initial concentration of carbohydrates for every feeding cycle could be calculated

16 using the following equation:

$$
\mathrm{S}=\mathrm{S}_{0}-\left(\mathrm{S}_{0}-\mathrm{S}_{\mathrm{in}}\right) \times \mathrm{e}^{-(\mathrm{Q} / \mathrm{V}) \times \mathrm{t}}
$$

18 where $\mathrm{S}$ is the resulting concentration when feeding was completed, $\mathrm{S}_{0}$ is the influent

19 concentration, $S_{\text {in }}$ is the concentration when feeding started, namely the concentration measured

20 at the end of each cycle, $\mathrm{Q}$ is the volumetric feeding rate, $\mathrm{V}$ is the reactor volume and $\mathrm{t}$ is the

21 duration of feeding. 
1 During start-up, in both experimental periods, the reactor was filled with SFIW and operated

2 anaerobically in batch mode for $48 \mathrm{~h}$, in order to activate the microbial species able to degrade

3 the wastewater, as proposed by Antonopoulou et al. (2008).

4 In the first series of experiments in which the effect of HRT was investigated, following start-up,

5 the operation of the reactor was subsequently switched to continuous mode at the HRT of $12 \mathrm{~h}$,

6 (days1-20), and then the HRT was gradually reduced to $8 \mathrm{~h}$ (days $21-39$ ), $6 \mathrm{~h}$ (days 40-48) and

7 finally $4 \mathrm{~h}$ (days 49-54), ensuring in each case that a steady state was reached. The SFIW was also

8 supplemented with $5 \mathrm{~g} / \mathrm{L} \mathrm{NaOH}$ and $6.8 \mathrm{~g} / \mathrm{L} \mathrm{KH}_{2} \mathrm{PO}_{4}$ (Buffer Solution or BS) in order to maintain

9 the $\mathrm{pH}$ of the acidogenic reactor, at the suitable levels for hydrogen production (almost 5-6).

10 Furthermore, $0.5 \mathrm{~g} / \mathrm{L}$ yeast extract and $2 \mathrm{~g} / \mathrm{L}$ of urea $\left(\mathrm{NH}_{2} \mathrm{CONH}_{2}\right)$ were added, since from

11 preliminary batch experiments it was shown that both compounds led to high hydrogen yields

12 (data not presented).

13 In order to investigate the effect of the $\mathrm{pH}$ on the production of hydrogen from SFIW, a second 14 start-up of the reactor was made. Following start-up, the reactor HRT was maintained constant at

$1512 \mathrm{~h}$, throughout the experimental period. The different $\mathrm{pH}$ values $(5-5.9)$ were achieved by 16 changing the ratio of the BS components. Initially, the reactor was fed with the SFIW 17 supplemented with the BS and when the reactor reached a steady state, the concentration of the BS 18 components was decreased to $3 / 4$ of the initial one (corresponding to $3.75 \mathrm{~g} / \mathrm{L} \mathrm{NaOH}$ and $5.1 \mathrm{~g} / \mathrm{L}$ $\left.19 \mathrm{KH}_{2} \mathrm{PO}_{4}\right)(3 / 4 \mathrm{BS})$. In the sequel, and after each steady state was established, the concentrations of 20 the BS components were gradually reduced until no buffer solution was added (0BS). Specifically,

21 there were six distinct experimental periods referring to the BS concentration: a) BS b) 3/4 BS c)

$221 / 2 \mathrm{BS}$ (corresponding to $2.5 \mathrm{~g} / \mathrm{L} \mathrm{NaOH}$ and $\left.\left.3.4 \mathrm{~g} / \mathrm{L} \mathrm{KH}_{2} \mathrm{PO}_{4}\right) \mathrm{d}\right) 1 / 3 \mathrm{BS}(1.67 \mathrm{~g} / \mathrm{L} \mathrm{NaOH}$ and $\left.232.271 \mathrm{~g} / \mathrm{L} \mathrm{KH} \mathrm{KH}_{2} \mathrm{PO}_{4}\right)$ e) $1 / 4 \mathrm{BS}\left(1.25 \mathrm{~g} / \mathrm{L} \mathrm{NaOH}\right.$ and $\left.1.7 \mathrm{~g} / \mathrm{L} \mathrm{KH}_{2} \mathrm{PO}_{4}\right)$ f) 0 BS. It has to be 
1 mentioned that during all the experimental period, urea and yeast extract were added to the feed

2 with concentrations of $0.5 \mathrm{~g} / \mathrm{L}$ and $2 \mathrm{~g} / \mathrm{L}$, respectively, in order to have the same conditions with

3 the first series of experiments.

4 At the HRTs of 12 and $8 \mathrm{~h}$, the reactor performance (biogas production rate and composition in 5 hydrogen, $\mathrm{pH}$, carbohydrates (total and soluble), soluble COD (sCOD), VFAs and lactate 6 concentration) was monitored once a day, six times a week, while at the HRT of 6 and $4 \mathrm{~h}$, the 7 reactor performance monitoring was performed twice and three times per day, respectively. At 8 each sampling, one sample was taken under constant agitation of the reactor, so as to ensure its 9 homogeneity, while triplicate measurements/analysis were conducted. Complete characterization was carried out when a steady state was reached. Steady state was assumed, once the variation of 11 the monitored parameters was less than $10 \%$, for at least 5 successive measurements. For the HRT 12 of $12 \mathrm{~h}$, the experimental period of days 13-20 (the steady state values of the main parameters 13 were calculated based on the mean values of 8 samples) was considered as a steady state, for the 14 HRT of $8 \mathrm{~h}$ a period of days 25-38 (the main parameters' steady state values corresponded to the 15 mean values of 14 samples), for the HRT of $6 \mathrm{~h}$ the experimental period of days 42-48 (13 16 samples were taken into account so as to estimate the mean values of main parameters) and finally

17 for the HRT of $4 \mathrm{~h}$ the period of days 51-54 (12 samples) was respectively considered as a steady 18 state. The biogas samples were analysed for methane regularly, in order to monitor whether methane production occurred.

\subsection{DNA extraction}


1 Total DNA extraction using on the average $10^{6}$ cells, was carried out using the Macherey-Nagel

2 Tissue kit following the manufacturer's protocol. Extracted DNA was stored at $-20^{\circ} \mathrm{C}$ until further 3 use.

4

\subsection{Microbial community analysis}

6 Sequencing was performed as described elsewhere (Carmona-Martinez et al., 2015). In

7 summary, the V3-4 region of the 16S rRNA gene was amplified with specific primers over 30

8 amplification cycles. In a second PCR reactor of 12 cycles, an index sequence was added. The

9 resulting PCR products were then purified and loaded onto the Illumina MiSeq cartridge

10 according to manufacturer's instructions for further sequencing. Data were then analysed

11 according to Chatellard et al. (2016). Sequences were pre-clustered at 4 differences in

12 nucleotides over the length of the amplicon. Scarce sequences appearing less than three times

13 within the data-set were removed. Alignment and taxonomic affiliation from the 16S rRNA

14 sequences was performed by Mothur with the SILVA SSU Ref NR99, release 119 database.

15 Final Operational Taxonomic Unit sequences have been submitted to GenBank database under

16 the accession numbers KY682109 - KY682171.

\subsection{Analytical methods}

19 Determinations of sCOD, Total Suspended Solids (TSS) and Volatile Suspended Solids (VSS)

20 were carried out according to Standard Methods (APHA, 2005). The concentrations of the VFAs

21 (acetic, propionic, iso-butyric, butyric, iso-valeric, valeric) were determined with a gas

22 chromatograph (VARIAN CP-30), equipped with a flame ionization detector and a capillary

23 column (Agilent technologies, INC. $30 \mathrm{~m} \times 0.53 \mathrm{~mm}$ ). The oven was programmed from $105{ }^{\circ} \mathrm{C}$ to 
$1 \quad 160{ }^{\circ} \mathrm{C}$ at a rate of $15^{\circ} \mathrm{C} / \mathrm{min}$ and subsequently to $235^{\circ} \mathrm{C}$ (for $3 \mathrm{~min}$ ) at a rate of $20^{\circ} \mathrm{C} / \mathrm{min}$.

2 Helium was used as the carrier gas at $15 \mathrm{~mL} / \mathrm{min}$, the injector temperature was set at $175^{\circ} \mathrm{C}$ and

3 the detector at $225^{\circ} \mathrm{C}$ and $200{ }^{\circ} \mathrm{C}$. Lactic acid concentration was measured with Megazyme D-/L-

4 Lactic acid assay kits. For the quantification of the carbohydrates, a colored sugar derivative was

5 produced through the addition of L-tryptophan and sulphuric and boric acids and subsequently

6 measured colorimetrically at $520 \mathrm{~nm}$ (Joseffson, 1983). The produced gas composition in

7 hydrogen and methane was quantified with a gas chromatograph (SRI 8610c MG\#1), equipped

8 with a thermal conductivity detector and a packed column. The carrier gas was nitrogen for

9 hydrogen measurements and helium for methane. The injector, column and detector temperatures

10 were set at $90{ }^{\circ} \mathrm{C}, 35^{\circ} \mathrm{C}$ and $100{ }^{\circ} \mathrm{C}$, respectively. The volume of the produced gas was measured

11 by the method of displacement of acidified water. The measurement of the $\mathrm{pH}$ was done using a

12 HANNA ( $\mathrm{pH} 211) \mathrm{pH}-$ meter with a HANNA electrode (HI 1230).

\section{Results and Discussion}

18 In the first series of experiments, where the effect of the HRT was investigated, the acidogenic reactor was operated anaerobically for 54 days. As previously mentioned, the reactor was initially

20 operated at an HRT $=12 \mathrm{~h}$ and the HRT was gradually reduced to $8 \mathrm{~h}, 6 \mathrm{~h}$ and finally $4 \mathrm{~h}$, ensuring

21 in each case that a steady state was reached. It is also worth to mention that, during the operation

22 of the hydrogen producing reactor, no methane was detected, as confirmed by methane 23 measurements. 
1 In figure 1, the hydrogen content in the gas phase as well as the hydrogen production rate at all

2 HRTs, are both presented. A long and stable operation with high hydrogen content in the gas

3 phase was observed, as the hydrogen content in the biogas varied between 50 and $60 \%$. As

4 anticipated, the biogas and hydrogen production rates increased when the HRT decreased. At an

5 HRT of $12 \mathrm{~h}$, the hydrogen production rate was $1.65 \pm 0.06 \mathrm{~L} \mathrm{H}_{2} / \mathrm{d}$, which gradually increased

6 when the HRT decreased. Thus, the highest hydrogen and biogas production rates were observed

7 for $\mathrm{HRT}=4 \mathrm{~h}$ and were $4.32 \pm 0.08 \mathrm{~L} \mathrm{H}_{2} / \mathrm{d}$ and $7.03 \pm 0.15 \mathrm{~L}$ biogas/d, respectively. From table 2,

8 a maximum production rate equal to $10.79 \pm 0.21 \mathrm{~L} \mathrm{H}_{2} / \mathrm{L}$ reactor/d, was observed at a HRT of $4 \mathrm{~h}$,

9 which is much higher compared to the respective obtained in similar reactor systems using

10 indigenous microbial species as inoculum (Antonopoulou et al., 2008; Venetsaneas et al., 2009).

11 On the other hand, although the hydrogen production rate was maximum at shorter HRT values,

12 the highest hydrogen production yields, in terms of $\mathrm{L} \mathrm{H}_{2} / \mathrm{kg} \mathrm{FIW}$, were obtained at the HRTs of

$1312 \mathrm{~h}$ and $6 \mathrm{~h}$, and were as high as $96.27 \pm 3.36$ and $101.75 \pm 3.71$, respectively, indicating that an

14 HRT range between 6 and $12 \mathrm{~h}$ seems to be efficient for fermentative hydrogen production from

15 this substrate. Regarding the yields of hydrogen production, expressed in terms of mol/mol of total

16 carbohydrates consumed, the highest hydrogen yields were observed at the shortest HRT values.

17 This could be attributed to the fact that at these HRT values, the hydrogen production efficiency

18 increased, while the carbohydrates removal efficiency decreased. Indeed, from figure 2 and table

192 , where the concentration of the non-consumed carbohydrates, expressed as glucose equivalents,

20 can be seen, it is obvious that for the first two HRT values (12 and $8 \mathrm{~h}$ ), the total carbohydrates'

21 concentration was $1.62 \pm 0.02$ and $2.12 \pm 0.15 \mathrm{~g} / \mathrm{L}$, respectively and the total carbohydrates'

22 consumption was $86.97 \pm 1.55 \%$ and $82.96 \pm 1.98 \%$, respectively. At the HRT of $6 \mathrm{~h}$, a slight

23 increase in their concentration was observed $(3.10 \pm 0.21 \mathrm{~g} / \mathrm{L})$ and the carbohydrates' consumption 
was equal to $75.06 \pm 0.88 \%$. At the HRT of $4 \mathrm{~h}$ a significant portion of the carbohydrates was not consumed $(4.80 \pm 0.23 \mathrm{~g} / \mathrm{L})$. Here, a reduction in carbohydrates' consumption $(61.38 \pm 2.33 \%)$ was observed, indicating that the reactor was kinetically limited at such a low HRT. The fact that the hydrogen production rate increased although the carbohydrates removal efficiency decreased at low HRTs, could be a strong indication that hydrogen might be also produced from sources other than carbohydrates. It is well known that SFIW is rich in proteins i.e. $0.11 \mathrm{~g} / \mathrm{g}$ of the FIW used in this study composed of proteins, based on Alexandropoulou et al. (2016), which might be hydrolysed to amino acids, and could be further metabolized during acidogenesis, to hydrogen and VFAs (Batstone et al., 2002). The fact that the hydrogen yield values ranging from $1.59 \pm 0.15$ to $2.47 \pm 0.05 \mathrm{~mol} / \mathrm{mol}$ carbohydrates consumed were higher compared with studies using similar reactor systems and conditions (Antonopoulou et al., 2008; 2010; 2011), corroborates this argument.

It is worth to mention that hydrolysis occurred in the acidogenic reactor, even at low HRT values. Although the soluble carbohydrates content and the sCOD were $7.94 \pm 0.35 \mathrm{~g} / \mathrm{L}$ and $12.85 \pm 1.90$ $\mathrm{g} / \mathrm{L}$, respectively, based on the SFIW characteristics, presented in table 1 , the SCOD of the reactor at each steady state varied between $15.59 \pm 0.69$ and $17.10 \pm 0.30 \mathrm{gCOD} / \mathrm{L}$. The fact that the sCOD of the reactor was higher than the respective sCOD of the feed corroborates the argument that hydrolysis reactions of carbohydrates or proteins or lipids, might have taken place in the reactor, at all HRT values tested.

The reactor pH slightly varied between 5.46- 5.72. According to Kothari et al. (2012), this $\mathrm{pH}$ range $(5.5-6.0)$ is ideal for avoiding methanogenesis, which is a key factor for establishing a stable and effective hydrogen generation process. The $\mathrm{pH}$ range of the present study, is slightly higher than the one reported by Antonopoulou et al. (2008) who studied fermentative hydrogen 
1 production from sweet sorghum extract, under different HRT values. In that study, the highest

2 hydrogen yield was obtained for a $\mathrm{pH}$ value of 5.3. However, although the aforementioned studies

3 report that the optimum $\mathrm{pH}$ values for fermentative hydrogen production lies between 5 and 5.7,

4 different values have also been reported as optimum for fermentation. For example, Wang et al.

5 (2010), who studied biological hydrogen production from kitchen waste in a CSTR, reported an

6 operational $\mathrm{pH}$ value of 4.4. Furthermore, Valdez-Vazquez et al. (2009) who used a waste

7 consisting of $60 \% \mathrm{FW}$ and $40 \%$ paper, for fermentative hydrogen production in a semi-continuous

8 reactor, reported a $\mathrm{pH}$ value of 6.4 as optimum. This could be attributed to different kinds of

9 inocula used, different substrates or reactor types and sometimes, to the difference in the $\mathrm{pH}$ range

10 studied (Wang et al., 2009).

11 The concentrations of the main metabolic products measured during the operational period of the

12 hydrogen producing reactor, under different HRT values are also depicted in figure 2, while their

13 steady states values are presented in table 2. Iso-butyric and iso-valeric were not detected

14 throughout the experimental period, while valeric acid and propionic acids were produced in small

15 quantities. The low concentrations of propionic acid indicate an efficient hydrogen production

16 process, as the formation of propionate leads to lower hydrogen yields (Guo et al., 2010;

17 Sivagurunathan et al. 2015). It is obvious that a different distribution of metabolic products

18 occurred at various HRT values. At the HRT of $12 \mathrm{~h}$, the dominant metabolic products were both

19 acetic and butyric acids, with a concentration of $2.94 \mathrm{~g} / \mathrm{L}$ and $3.19 \mathrm{~g} / \mathrm{L}$, respectively. For the HRT

20 of $8 \mathrm{~h}$, butyric acid production prevailed (4.71 g/L), while the concentration of acetic acid

21 decreased to $2.00 \mathrm{~g} / \mathrm{L}$. At the same conditions, production of lactic acid occurred at a

22 concentration of $0.77 \mathrm{~g} / \mathrm{L}$. At the HRT of $6 \mathrm{~h}$, both butyric and lactic acid dominated, with

23 concentrations of $3.46 \mathrm{~g} / \mathrm{L}$ and $2.89 \mathrm{~g} / \mathrm{L}$, respectively and finally at the HRT of $4 \mathrm{~h}$, lactic acid 
1 prevailed as the dominant metabolic product $(3.03 \mathrm{~g} / \mathrm{L})$ while the concentration of butyric acid

2 reduced to $2.45 \mathrm{~g} / \mathrm{L}$.

3 Regarding lactic acid production, its concentration increased with the HRT reduction to 6 and $4 \mathrm{~h}$

4 and was maximized at the lowest HRT value. It can be assumed that lactate is an intermediate

5 metabolic product, which is converted to other products, such as acetate and propionate (Reaction

6 1) (Antonopoulou et al., 2008; Alexandropoulou et al., 2016). At the higher HRT value of $12 \mathrm{~h}$,

7 lactate is totally converted to products, while at the lower HRT values, lactate is accumulated, due

8 to kinetic limitation of its consumption to acetic and propionic acids, according to the reaction:

$$
3 \mathrm{CH}_{3} \mathrm{CHOHCOOH} \rightarrow 2 \mathrm{CH}_{3} \mathrm{CH}_{2} \mathrm{COOH}+\mathrm{CH}_{3} \mathrm{COOH}+\mathrm{CO}_{2}+\mathrm{H}_{2} \mathrm{O}
$$

10 The experimental results obtained are in agreement with previous observations of

11 Alexandropoulou et al. (2016) who reported that the maximum concentration of lactic acid was

12 obtained for the shortest HRT value (2 h), when using an Up-Flow Column Reactor fed with the

13 soluble fraction coming from extraction of FIW, at the HRTs of 12 to $2 \mathrm{~h}$. In addition, a higher

14 lactate concentration was also observed at the HRT of $1.5 \mathrm{~h}$, when beverage wastewater was used 15 as substrate in a continuous reactor with immobilized cells, at HRT values from 1.5 to $8 \mathrm{~h}$

16 (Sivagurunthan et al., 2015).

17 It is widely accepted that hydrogen yields correlate with the distribution of the metabolic products and the respective pathways followed by the different microbial populations. According to the

19 pathways leading to acetic, butyric and propionic acids production, the theoretical hydrogen rate

20 can be calculated as the sum of the hydrogen produced through glucose fermentation to acetic and

21 butyric acid (reactions 2 and 3), after subtracting the hydrogen produced through the reaction of

22 glucose conversion to propionic acid (reaction 4) (Antonopoulou et al., 2011). Alternatively,

23 taking into account that acetic and propionic acid might be produced through other reactions 
1 which are not accompanied by hydrogen production/consumption, the theoretical hydrogen rate

2 can be calculated based on the reaction (3).

3 Acetic acid production $\quad \mathrm{C}_{6} \mathrm{H}_{12} \mathrm{O}_{6}+2 \mathrm{H}_{2} \mathrm{O} \rightarrow 2 \mathrm{CH}_{3} \mathrm{COOH}+2 \mathrm{CO}_{2}+4 \mathrm{H}_{2}$

4 Butyric acid production $\quad \mathrm{C}_{6} \mathrm{H}_{12} \mathrm{O}_{6} \rightarrow \mathrm{CH}_{3} \mathrm{CH}_{2} \mathrm{CH}_{2} \mathrm{COOH}+2 \mathrm{CO}_{2}+2 \mathrm{H}_{2}$

5 Propionic acid production

$\mathrm{C}_{6} \mathrm{H}_{12} \mathrm{O}_{6}+2 \mathrm{H}_{2} \rightarrow 2 \mathrm{CH}_{3} \mathrm{CH}_{2} \mathrm{COOH}+2 \mathrm{H}_{2} \mathrm{O}$

6 In table 3 the mean values of the theoretically calculated hydrogen production rates based on

7 reactions (2) -(4), as well as the respective rates based only on the reaction (3), are compared with

8 the experimentally measured ones. As it is obvious, in all cases, the measured hydrogen

9 production rate was much lower than the theoretically calculated based on all metabolic products

10 measured (reactions (2)-(4)). Therefore, it could be assumed, that acetic acid is partially or

11 completely produced through the following reaction, i.e., reaction (5), where no hydrogen is

12 produced during glucose degradation, while hydrogen production is correlated to butyrate

13 production via reaction (3).

$$
\mathrm{C}_{6} \mathrm{H}_{12} \mathrm{O}_{6} \rightarrow 3 \mathrm{CH}_{3} \mathrm{COOH}
$$

15

16

17

18

19

20

21

22

23

24

Also, it could be assumed that a fraction of hydrogen could be produced via other pathways, during aminoacids acidogenesis (Batstone et al., 2002).

For example, for the HRT of $12 \mathrm{~h}$, the measured hydrogen production rate was almost equal to the respective rate calculated, taking into account only the concentration of butyric acid produced. This indicates that under these conditions, the dominant pathway that the microorganisms followed was the respective described by the reaction (3), where sugars were converted to butyric acid and hydrogen. 
1 The experimental period in which the effect of $\mathrm{pH}$ value on hydrogen production efficiency from

2 SFIW was investigated, lasted 80 days. The working HRT value was selected at $12 \mathrm{~h}$, based on the

3 results from the previous series of experiments, where the HRT range between $6-12 \mathrm{~h}$ was

4 observed to be optimum for the continuous fermentative hydrogen production from SFIW $(96.27 \pm$

$53.36 \mathrm{LH}_{2} / \mathrm{kg} \mathrm{FIW}$ ). As mentioned before, there were six distinct experimental periods referring to

6 the buffer solution concentration (a) BS b) $3 / 4 \mathrm{BS} \mathrm{c}$ ) $1 / 2 \mathrm{BS}$ d) $1 / 3 \mathrm{BS}$ e) $1 / 4 \mathrm{BS}$ and f) $0 \mathrm{BS}$ ) in

7 order to investigate the effect of the $\mathrm{pH}$ on the bioprocess performance. It should be noted that

8 during the operation of the hydrogenogenic reactor, no traces of methane were detected at any

9 time, indicating absence or inhibition of methanogens in the microbial consortium.

10 The $\mathrm{pH}$ varied from $5.91 \pm 0.07$ to $5.00 \pm 0.32$, due to the gradual reduction in the buffer

11 capacity of the feeding, as shown in table 4 . Initially, the $\mathrm{pH}$ of the mixed liquor in the reactor

12 was $5.91 \pm 0.07$ (BS) and decreased gradually to $5.55 \pm 0.02,5.40 \pm 0.05,5.32 \pm 0.11$ and $5.31 \pm$

130.04 , when the concentration of the buffer solution components was reduced at $3 / 4$ (3/4 BS), $1 / 2$

14 (1/2 BS), 1/3 (1/3 BS) and 1/4 (1/4 BS) of the initial one, respectively. A further decrease of the

$15 \mathrm{pH}$ to $5.00 \pm 0.32$ occurred when no buffer solution was added (0 BS).

16 In figure 3, the percentage of hydrogen in the gas phase as well as the hydrogen production rate

17 during the experimental period, are presented. The mean values of the corresponding hydrogen

18 production rates and yields at each steady state are presented in table 4 . The percentage of the hydrogen in the gas phase of the reactor lied at high values between $46-54 \%$, indicating a

20 robust, stable, long-term operation over time. The experimental results are in contrast with the

21 respective obtained by Antonopoulou et al. (2010) who studied the continuous fermentative

22 hydrogen production from sweet sorghum extract under different $\mathrm{pH}$ values. Based on the results

23 obtained by Antonopoulou et al. (2010), the gradual reduction of the BS components led to a rapid 
1 decrease in the $\mathrm{pH}$ value below 4 , and consequently a cessation of hydrogen production, under

2 these conditions.

3 The efficiency of total carbohydrates consumption in glucose equivalents (table 4) lied between

$486.97 \pm 2.22 \%$ to $84.19 \pm 1.95 \%$, at the $\mathrm{pH}$ range of $5.91 \pm 0.07$ to $5.55 \pm 0.02$ (BS and $3 / 4 \mathrm{BS}$ )

5 and reduced to $61.55 \pm 3.01 \%$ and $63.79 \pm 2.06 \%$ for the $\mathrm{pH}$ range of $5.40 \pm 0.05$ and $5.31 \pm$

60.04 , respectively, when the concentration of BS components reduced from $1 / 2$ to $1 / 4$ of its initial

7 concentration. With further reduction of the $\mathrm{pH}$ value to $5.00 \pm 0.32$, the reactor was kinetically

8 limited, as the carbohydrates' consumption efficiency was reduced to $33.05 \pm 1.02 \%$ and the

9 carbohydrates' concentration was equal to $8.32 \pm \mathrm{g} / \mathrm{L}$, when no buffer solution was added (0BS).

11 From table 4, it can be seen that the maximum hydrogen production rate was observed for the $\mathrm{pH}$

12 value of $5.40 \pm 0.05(1 / 2 \mathrm{BS})$ and was equal to $2.43 \pm 0.06 \mathrm{~L} \mathrm{H}_{2} / \mathrm{d}$ or $6.06 \pm 0.16 \mathrm{~L} \mathrm{H}_{2} / \mathrm{L}$

13 reactor/d. However, high hydrogen production rates were also observed at all steady states, even

14 at the lowest $\mathrm{pH}$ value. At the $\mathrm{pH}$ value of $5.40 \pm 0.05(1 / 2 \mathrm{BS})$, the hydrogen yield reached its

15 highest value, amounting to $141.47 \pm 3.64 \mathrm{~L} \mathrm{H}_{2} / \mathrm{kg}$ FIW. This yield was $46.5 \%$ higher than the respective obtained when the $\mathrm{pH}$ was $5.91 \pm 0.07$ and the SFIW was supplemented with the BS.

17 This fact is beneficial for the economy of the process, since reduction of the $\mathrm{pH}$ from $5.91 \pm 0.07$

18 to $5.40 \pm 0.05$ means a $50 \%$ reduction of chemicals (from BS to $1 / 2 \mathrm{BS}$ ), with a parallel

19 significant increase in the hydrogen yields. In general, the operation of a hydrogen producing

20 reactor at low $\mathrm{pH}$ values could be advantageous, since this involves the addition of less alkali for

$21 \mathrm{pH}$ control, incurring less cost. However, further reduction of BS capacity to $1 / 3$ and $1 / 4$ of the

22 initial one (1/3 BS and 1/4 BS) corresponded to a yield of $93.37 \pm 2.39$ and $89.23 \pm 2.65 \mathrm{~L} \mathrm{H}_{2} /$

23 kg FIW, respectively, while a yield of $85.90 \pm 1.82 \mathrm{~L} \mathrm{H}_{2} / \mathrm{kg}$ FIW was observed, when no buffer 
was added. These values were similar compared with the hydrogen yield at the $\mathrm{pH}$ of $5.91 \pm$ 0.07, when BS was added, indicating that high hydrogen yields were observed during all the operational period. In order to decide for the optimal $\mathrm{pH}$ value for a full-scale plant, it is necessary to take into account both economic (based on chemical costs) and technical (based on hydrogen yield) aspects.

Regarding the yields expressed in terms of $\mathrm{mol} \mathrm{H}_{2} / \mathrm{mol}$ total carbohydrates consumed, high hydrogen yields can be observed at the $\mathrm{pH}$ value of $5.40 \pm 0.05$, while the highest yield was observed at a pH of $5.00 \pm 0.32(0 \mathrm{BS})(3.73 \pm 0.20)$. This could be attributed to the fact that at this $\mathrm{pH}$ value, the hydrogen production efficiency was high, while the carbohydrates removal efficiency was significantly low. The fact that the hydrogen production rate was at high levels although the reactor was kinetically limited, could be a strong indication that under these conditions, hydrogen might be produced also from sources other than carbohydrates. This was also assumed for hydrogen production under low HRT values.

Based on the present study, the optimal $\mathrm{pH}$ for fermentative hydrogen production from SFIW seems to lie between $5.40 \pm 0.05$ and $5.00 \pm 0.32$. Lay (2000) reported that hydrogen production occurred within a $\mathrm{pH}$ range between 4.7 and 5.7 with an optimum $\mathrm{pH}$ value of 5.2 , when a continuous bioreactor operated with mixed microbial cultures processing starch at an HRT of 17 h. In addition, Antonopoulou et al. (2010) suggested a $\mathrm{pH}$ value of 4.7 as optimum from an economical point of view, for hydrogen production from sweet sorghum extract, since hydrogen productivity and yields were at high levels for the $\mathrm{pH}$ range of 4.7 - 5.3. Although there is a wide range of $\mathrm{pH}$ values which have been reported as optimum in dark continuous fermentation, it is well known that an acidic operational $\mathrm{pH}$ enhances the bioprocess efficiency, as mainly it 
1 inhibits the methanogenic activity under both mesophilic and thermophilic conditions (Ghimire

2 et al., 2015b).

3 In figure 4, the distribution of the soluble metabolites during the operational period is presented,

4 while the mean values of their concentrations measured at each steady state are presented in table

5 4. Iso-valeric acid was not detected, while valeric and iso-butyric acids were produced in small

6 quantities under these conditions. The main metabolic products detected were acetic, butyric and

7 propionic acids. Acetic acid generation was favored at high $\mathrm{pH}$ values reaching the highest

8 concentration of $2.65 \mathrm{~g} / \mathrm{L}$ at the $\mathrm{pH}$ of 5.91 . As presented in the figure 4 , the dominant metabolic

9 product, at all steady states, was butyric acid. Its concentration was 4.15 and $4.89 \mathrm{~g} / \mathrm{L}$, at $\mathrm{pH}$

10 values of $5.55(3 / 4 \mathrm{BS})$ and $5.40(1 / 2 \mathrm{BS})$, respectively and decreased when the $\mathrm{pH}$ was lower or

11 higher than those values. This observation verified that the hydrogen yield was related to the

12 production of butyrate (reaction 3) (Hawkes et al., 2002; Antonopoulou et al., 2008;

13 Antonopoulou et al., 2011), since reduction of butyrate concentration was accompanied by a

14 proportional decrease of hydrogen. Moreover, higher hydrogen yields were achieved when

15 butyrate was the main metabolic product, at the operational periods of $3 / 4 \mathrm{BS}$ and $1 / 2 \mathrm{BS}$.

16 Lactic acid, on the other hand, was produced at low concentrations, when the BS concentration

17 significantly decreased (1/4 BS and $0 \mathrm{BS}$ ), something that caused a hydrogen yield decrease. As

18 previously mentioned, lactate was assumed to be an intermediate product, which at the HRT of 12

$19 \mathrm{~h}$ and a high $\mathrm{pH}$ range of 5.91 to 5.32 was almost totally consumed to other products. When the

$20 \mathrm{pH}$ decreased to $5.00 \pm 0.32(0 \mathrm{BS})$, the lactate production rate seems to be higher than its

21 consumption rate, so that small quantities of lactic acid were observed. This is a strong indication

22 that the $\mathrm{pH}$ is a crucial parameter, affecting the rates of the kinetic reactions and subsequently the

23 distribution of metabolites, even at the same HRT value. 
1 It is also worth to mention that the hydrogen yields and rates obtained from the first series of

2 experiments, in which the effect of HRT was studied, are almost identical with the respective of

3 this experimental period at the same conditions ( $\mathrm{HRT}=12 \mathrm{~h}$, and $\mathrm{pH}=5.91 \pm 0.07(\mathrm{BS})$ ),

4 verifying the repeatability of the experimental results. In addition, the start-up of the reactor (even

5 at different time periods when the experimental series were conducted) was performed using the

6 indigenous microbial consortium of FIW, which has a relatively fixed composition, which in turn

7 implies that the metabolic pathways implicated in the overall process are not expected to alter,

8 under certain conditions, verifying thus the repeatability of the experiments.

9 In table 5, the mean values of the theoretically calculated hydrogen production rates based on reactions (2) -(4), as well as the respective rates based only on the reaction (3), are compared with

11 the experimentally measured ones. It can be observed that in all cases, the measured hydrogen

12 production rate was much lower than the theoretically calculated, based on all metabolic products

13 measured (reactions (2)-(4)), as in case of the first series of experiments, while in most cases the

14 measured hydrogen production rate was higher compared to the respective rate calculated taking

15 into account only the concentration of the butyric acid produced (based only on reaction 3). Only

16 in the $\mathrm{pH}$ values of $5.32 \pm 0.11$ and $5.31 \pm 0.04(1 / 3$ and $1 / 4 \mathrm{BS})$, which were quite similar and

17 resulted in almost the same metabolic profile (table 4), the measured hydrogen was similar to the

18 hydrogen based on the reaction (3). The fact that the measured hydrogen was higher compared to

19 the respective calculated taking into account only the concentration of butyric acid, is an

20 indication that either hydrogen could be also produced via sources other than sugars (such as

21 aminoacids) or that a portion of hydrogen is also produced via the acetate production pathway, via

22 reaction (2), while a portion of acetate is also produced from reaction (5). Thus, the $\mathrm{pH}$ influences 
1 the rates of different reactions which are carried out during the metabolic pathways which are

2 followed by the involved metabolic products.

3

4

5

6

7

\subsection{Microbial community analysis}

Characterization of the microbial community was performed at various $\mathrm{pH}$ values, giving thus a deeper insight in the well-established hydrogen production process from FIW since the possible biochemical pathways which were followed by the microbial consortium, under different operational conditions were elucidated. Samples for microbial community analysis were taken from the reactor, corresponded to the six distinct operational periods (BS, 3/4 BS, 1/2 BS, 1/3 BS, 1/4 BS, 0 BS). The analysis revealed that samples taken from the steady states of the operational period $\mathrm{BS}, 3 / 4 \mathrm{BS}, 1 / 2 \mathrm{BS}$, where the $\mathrm{pH}$ ranged from $5.91 \pm 0.07$ to $5.40 \pm 0.05$, had the same microbial community structures. Similarly, the samples taken from the operational periods $1 / 3 \mathrm{BS}$ and 1/4 BS were considered as similar $(\mathrm{pH}: 5.32 \pm 0.11$ and $5.31 \pm 0.04)$. Thus, the phylogenetic taxonomy is presented for the operational periods of $3 / 4 \mathrm{BS}(\mathrm{pH}: 5.55 \pm 0.02), 1 / 3 \mathrm{BS}(\mathrm{pH}: 5.32 \pm$ 0.11 ) and 0 BS (pH: $5.00 \pm 0.32$ ), where different microbial community structures were distinguished (Figure 5). Overall, the microbial diversity was very low all along the experiment, with only five families having relative abundances higher than $2 \%$. The main bacteria detected to all samples were affiliated to the Clostridiaceae, Lactobacillaceae, Enterobacteriaceae and Ruminococcaceae families. Also, for the sample where the BS concentration was $3 / 4$ of the initial one (3/4 BS), Lachnospiraceae family was detected. As it can be seen, when the $\mathrm{pH}$ was $5.55 \pm$ 0.02 (3/4 BS sample) and $5.32 \pm 0.11(1 / 3 \mathrm{BS})$, the composition profile was dominated by members of the Clostridiaceae family, corresponding to $87 \%$ and $72 \%$ of the identified bacteria, respectively. The high abundance in genus Clostridium which is accompanied by concomitant 
1 accumulation of butyric acid, justifies the highest hydrogen rates and yields which were obtained

2 under these conditions, as commonly observed (Chatellard et al. 2016). In addition, $3 \%$ (3/4 BS)

3 and $13 \%(1 / 3 \mathrm{BS})$ of the microbial culture were affiliated to the Rumicoccaceae family. Since

4 Rumicoccaceae members have also been described as hydrogen-producing bacteria (HPB)

5 (Chatellard et al. 2016), it can be concluded that more than $90 \%$ of the bacterial community was

6 composed of HPB, when the pH value was both $5.55 \pm 0.02$ (3/4 BS sample) and $5.32 \pm 0.11(1 / 3$

7 BS). Interestingly, Chatellard et al. (2016) found that Ruminoccocaceae were enriched in a

8 hydrolytic environment with cellulose-based substrates. This suggests that using complex sugar-

9 rich substrates such as the starchy baby foods of the present study, induced a selection pressure

10 highly oriented towards HPB on both simple and complex carbohydrates at low $\mathrm{pH}$. This

11 observation also supports the fact that hydrogen production depends on metabolic pathways

12 involving carbohydrates rather than proteins or lipids degradation, as previously shown by Monlau

13 et al. (2012). The fact that in samples $3 / 4$ BS (which exhibited similar microbial community

14 structure profile with that of BS and $1 / 2 \mathrm{BS}$ ) and $1 / 3 \mathrm{BS}$ (which exhibited similar profile with that

15 of $1 / 4 \mathrm{BS}$ ), more than $85 \%$ of the community composed by Clostridiaceae/Ruminococcaceae, is

16 consistent with the high hydrogen production rates and yields, obtained during the experiments

17 (table 4).

18 In contrast, when no BS was added in the reactor and the $\mathrm{pH}$ dropped to $5.00 \pm 0.32$, a shift in the bacterial distribution was observed, with an emergence of Enterobacteriaceae up to $69 \%$

20 replacing Clostridiaceae, which were only $27 \%$ of the total microbial community. During this

21 period, the ratio of butyrate to acetate was lowered due to a high decrease of butyrate

22 concentration (from $4.15 \pm 0.19 \mathrm{~g} / \mathrm{L}$ when the reactor was supplemented with $3 / 4 \mathrm{BS}$ to $2.49 \pm$

$23 \quad 0.17 \mathrm{~g} / \mathrm{L}$ when no BS was added) and the hydrogen production rate decreased. In addition, the 
1

reactor was kinetically limited, since a high portion of the total and soluble carbohydrates was not consumed, under these conditions. In other words, the different distribution of metabolites at this $\mathrm{pH}$ value, is justified by the different distribution of bacteria which prevailed in the reactor.

Finally, during all the experimental periods, a small portion of the bacteria was affiliated to Lactobacillaceae (3-9\%) families. The fact that lactic acid accumulated amongst the metabolites, even at low concentrations, since it was assumed that lactate was an intermediate metabolic product which was mainly accumulated under low HRT values $(4 \mathrm{~h})$, could be verified by the intensification of lactic-acid producing bacteria belonging to Lactobacillaceae family.

(1)

\section{Conclusions}

Fermentative hydrogen production of food industry waste (FIW) was investigated in a continuous type reactor, under various HRT and $\mathrm{pH}$ values. The results showed a long and stable reactor operation with high hydrogen production rates and yields at all HRTs tested. The optimal HRT range was found to be in the range $6-12 \mathrm{~h}$. In the sequel, the effect of the culture $\mathrm{pH}$ was investigated, by changing the buffer solution (BS) components, while the HRT value was maintained at $12 \mathrm{~h}$. A stable reactor operation with high hydrogen production rates and yields was also observed at all $\mathrm{pH}$ values tested (from $5.00 \pm 0.32$ to $5.91 \pm 0.07$ ), while the optimum $\mathrm{pH}$ value was $5.40 \pm 0.05$. Characterization of the microbial community at the optimum $\mathrm{pH}$ value revealed that $90 \%$ of the bacterial community was composed of hydrogen producing bacteria affiliated to the Clostridiaceae/ Ruminococcaceae family, while lowering the $\mathrm{pH}$ leads to a relative enrichment of the Enterobacteriaceae family. 
1 The authors would like to thank General Secretariat for Research and Technology (GSRT) for

2 the financial support of this work under 'Nutrifuel' -SYNERGASIA_09SYN_32_621 as well as

3 'Bilateral projects Greece-France 2013-2015, -1455-FrancEllas, project for the collaboration

4 between both research groups. Also, they gratefully acknowledge Dr. Ntaikou Ioanna and Dr.

5 Kamilari Maria for their help in DNA extraction.

\section{References}

8 Alexandropoulou, M., Antonopoulou, G., Lyberatos, G., 2016. Food industry waste's 9 exploitation via anaerobic digestion and fermentative hydrogen production in an Up-Flow 10 Column Reactor. Waste Biomass Valor. 7(4), 711-723.

11 American Public Health Association (APHA), 2005. Standard Methods for the Examination of

12 Water and Wastewater, $21^{\text {st }}$ ed. American Public Health Association Water Works Association, 13 American Water Environment Federation, Washington, DC.

14 Antonopoulou, G., Gavala, H.N., Skiadas, I.V., Angelopoulos, K., Lyberatos, G., 2008. Biofuels

15 generation from sweet sorghum: fermentative hydrogen production and anaerobic digestion of the 16 remaining biomass. Bioresour. Technol. 9(1), 110-119.

17 Antonopoulou, G., Gavala, H.N., Skiadas, I.V., Lyberatos, G., 2010. Influence of pH on

18 fermentative hydrogen production from sweet sorghum extract. Int. J. Hydrogen Energy. 35(5), $19 \quad 1921-1928$.

20 Antonopoulou, G., Gavala, H.N., Skiadas, I.V., Lyberatos, G., 2011. Effect of substrate 21 concentration on fermentative hydrogen production of sweet sorghum extract. Int. J. Hydrogen 22 Energy. 36(8), 4843-4851. 
1 Arimi, M.M., Knodel, J., Kiprop, A., Namango, S.S., Zhang, Y., Geißen, S.-U., 2015. Strategies

2 for improvement of bio-hydrogen production from organic rich wastewater: A review. Biomass Bioenergy. 75, 101-118.

4 Batstone, D.J., Keller, J, Angelidaki, I., Kalyuzhnyi, S., Pavlostathis, S.G., Rozzi, A., Sanders,

5 W.T., Siegrist, H., Vavilin, V.A., 2002. Anaerobic Digestion Model No. 1 (ADM1) IWA

6 Scientific and Technical Report No. 13, IWA Publishing, London.

7 Cappai, G., De Gioannis, G., Friargiu, M., Massi, E., Muntoni, A., Polettini, A., Pomi, R., Spiga, D., 2014. An experimental study on fermentative $\mathrm{H}_{2}$ production from food waste as affected by

9 pH. Waste Management. 34(8), 1510-1519.

Carmona-Martínez, A.A., Trably, E., Milferstedt, K., Lacroix, R., Etcheverry, L., Bernet, N., 2015. Long-term continuous production of $\mathrm{H}_{2}$ in microbial electrolysis cell (MEC) treating saline wastewater. Water Res. 81, 149-156.

Castillo-Hernández, A., Mar-Alvarez, I., Moreno-Andrade, I., 2015. Start-up and operation of continuous stirred-tank reactor for biohydrogen production from restaurant organic solid waste. Int. J. Hydrogen Energy. 40, 17239-17245.

Chatellard, L., Trably, E., Carrère, H., 2016. The type of carbohydrates specifically selects microbial community structures and fermentation patterns. Bioresour. Technol. 221, 541-549

Cubillos, G., Arrué, R., Jeison, D., Chamy, R., Tapia, E., Rodríguez, J., Ruiz-Filippi, G., 2010. Simultaneous effects of $\mathrm{pH}$ and substrate concentration on hydrogen production by acidogenic fermentation. Electron. J. Biotechnol. 13(1).

Dung, T.N.B., Sen, B., Chen, C.-C., Kumar, G., Lin, C.-Y., 2014. Food waste to bioenergy via anaerobic processes. Energy Procedia. 61, 307-312. 
1 Galanakis, C.M., 2012. Recovery of high added-value components from food wastes:

2 Conventional, emerging technologies and commercialized applications. Trends Food Sci.

3 Technol. 26, $68-87$.

4 Ghimire, A., Frunzo, L., Pirozzi, F., Trably, E., Escudie, R., Lens, P.N.L., Esposito, G., 2015b. A

5 review on dark fermentative biohydrogen production from organic biomass: Process parameters 6 and use of by-products. Appl. Energy. 144, 73-95.

7 Ghimire, A., Valentino, S., Frunzo, L., Trably, E., Escudié, R., Pirozzi, F., Lens, P.N.L., 8 Esposito, G., 2015a. Biohydrogen production from food waste by coupling semi-continuous 9 dark-photofermentation and residue post-treatment to anaerobic digestion: A synergy for energy 10 recovery. Int. J. Hydrogen Energy. 40, 16045 - 16055.

11 Girotto, F., Alibardi, L., Cossu, R., 2015. Food waste generation and industrial uses: A review.

12 Waste Management. 45, $32-41$.

13 Guo, X.M., Trably, E., Latrille, E., Carrere, H., Steyer, J.-P., 2010. Hydrogen production from 14 agricultural waste by dark fermentation: A review. Int. J. Hydrogen Energy. 35(19), 10660-10673.

15 Han, W., Liu, D.N., Shi, Y.W., Tang, J.H., Li, Y.F., Ren, N.Q., 2015. Biohydrogen production 16 from food waste hydrolysate using continuous mixed immobilized sludge reactors. Bioresour.

17 Technol. 180, 54-58.

18 Hawkes, F.R., Dinsdale, R., Hawkes, D.L., Hussy, I., 2002. Sustainable fermentative hydrogen 19 production: challenges for process optimization. Int. J. Hydrogen Energy. 27, 1339-1347.

20 Joseffson, B., 1983. Rapid spectrophotometric determination of total carbohydrates. In:

21 Grasshoff, K., Ehrhardt, M., Kremling, K. (Eds.), Methods of Seawater Analysis. Verlag Chemie

$22 \mathrm{GmbH}$, Berlin, pp. 340-342. 
1 Karthic, P., Joseph, S., Arun, N., Varghese, L.A., Santhiagu, A., 2013. Biohydrogen production

2 using anaerobic mixed bacteria: Process parameters optimization studies. J. Renewable Sustain.

3 Energy. 5 (6), 063103. DOI: http://dx.doi.org/10.1063/1.4826192.

4 Kim, M.-S., Lee, D.-Y., 2010. Fermentative hydrogen production from tofu-processing waste

5 and anaerobic digester sludge using microbial consortium. Bioresour. Technol. 101, S48 - S52.

6 Kothari, R., Singh, D.P., Tyagi, V.V., Tyagi, S.K., 2012. Fermentative hydrogen production - An

7 alternative clean energy source. Renew. Sust. Energ. Rev. 16(4), 2337-2346.

8 Lay, J.-J., 2000. Modeling and optimization of anaerobic digested sludge converting starch to

9 hydrogen. Biotechnol. Bioeng. 68(3), 269-278.

Lee, D.-Y., Ebie, Y., Xu, K.-Q., Li, Y.-Y., Inamori, Y., 2010. Continuous $\mathrm{H}_{2}$ and $\mathrm{CH}_{4}$ production

11 from high-solid food waste in the two-stage thermophilic fermentation process with the

12 recirculation of digester sludge. Bioresour. Technol. 101, S42 - S47.

Li, C., Fang, H.H.P., 2007. Fermentative hydrogen production from wastewater and solid wastes

14 by mixed cultures. Crit. Rev. Environ. Sci. Technol. 37(1), 1-39. DOI:

15 http://dx.doi.org/10.1080/10643380600729071.

16 Matsakas, L., Kekos, D., Loizidou, M., Christakopoulos, P., 2014. Utilization of household food

17 waste for the production of ethanol at high dry material content. Biotechnology for Biofuels, 7:4.

18 Melikoglu, M., Lin, C.S.K., Webb, C., 2013. Analysing global food waste problem: pinpointing

19 the facts and estimating the energy content. Cent. Eur. J. Eng. 3 (2), $157-164$.

20 Monlau, F., Sambusiti, C., Barakat, A., Guo, X.M., Latrille, E., Trably, E., Steyer, J.P., Carrere,

21 H., 2012. Predictive models of biohydrogen and biomethane production based on the 
1 compositional and structural features of lignocellulosic materials. Env. Sci. Technol. 46 (21);

$2 \quad 12217-12225$

3 Moreno-Andrade, I., Cirillo-Reyes, J., Santiago, S.G., Bujanos-Adame, M.C., 2015.

4 Biohydrogen from food waste in a discontinuous process: Effect of HRT and microbial

5 community analysis. Int. J. Hydrogen Energy. 40, 17246 - 17252.

6 Muri, P., Črnivec, I.G.O., Djinović, P., Pintar, A., 2016. Biohydrogen production from simple

7 carbohydrates with optimization of operating parameters. Acta Chim. Slov. 63 (1), $154-164$.

8 Ntaikou, I., Antonopoulou, G., Lyberatos, G., 2010. Biohydrogen production from biomass and

9 wastes via dark fermentation: A review. Waste Biomass Valor. 1 (1), 21-39.

10 Sattar, A., Arslan, C., Ji, C., Chen, K., Nasir, A., Fang, H., Umair, M., 2016. Optimizing the

11 physical parameters for bio-hydrogen production from food waste co-digested with mixed

12 consortia of Clostridium. J. Renewable Sustain. Energy. 8(1), 013107. DOI:

13 http://dx.doi.org/10.1063/1.4939767.

14 Sivagurunathan, P., Sen, B., Lin, C-Y., 2015. High-rate fermentative hydrogen production from

15 beverage wastewater. Appl. Energy. 147, 1-9.

16 Thi, N.B.D., Lin, C.-Y., Kumar, G., 2016. Waste-to-wealth for valorization of food waste to

17 hydrogen and methane towards creating a sustainable ideal source of bioenergy. J. Clean. Prod.

$18 \quad 122,29-41$.

19 Valdez-vazquez, I., Ponce-Noyola, M.T., Poggi-Varaldo, H.M., 2009. Nutrients related to spore

20 germination improve $\mathrm{H}_{2}$ production from heat-shock-treated consortia. Int. J. Hydrogen Energy.

$2134(10), 4291-4295$. 
1 Venetsaneas, N., Antonopoulou, G., Stamatelatou, K., Kornaros, M., Lyberatos, G., 2009. Using

2 cheese whey for hydrogen and methane generation in a two-stage continuous process with

3 alternative pH controlling approaches. Bioresour. Technol. 100(15), 3713-3717.

4 Wang, J., Wan, W., 2009. Factors influencing fermentative hydrogen production: A review. Int. J.

5 Hydrogen Energy. 34(2), 799-811.

6 Wang, Y.-H., Li, S.-L., Chen, I.-C., Tseng, I.-C., Cheng, S.-S., 2010. A study of the process

7 control and hydrolytic characteristics in a thermophilic hydrogen fermentor fed with starch-rich

8 kitchen waste by using molecular-biological methods and amylase assay. Int. J. Hydrogen Energy.

$9 \quad 35(23), 13004-13012$.

10 Wongthanate, J., Chinnacotpong, K., 2015. Optimal conditions for biological hydrogen

11 production from food waste. Environment. Eng. Res. 20 (2), 121-125.

12 Wongthanate, J., Chinnacotpong, K., Khumpong, M., 2014. Impacts of pH, temperature and

13 pretreatment method on biohydrogen production from organic wastes by sewage microflora. Int.

14 J. Energy Env. Eng.. 5(1), 1-6.

15 Zhao, Q.-B., Yu, H.-Q., 2008. Fermentative $\mathrm{H}_{2}$ production in an upflow anaerobic sludge

16 blanket reactor at various pH values. Bioresour. Technol. 99(5), 1353-1358

17

18

19

20 


\section{Figure captions}

2 Figure 1 : The percentage of hydrogen in the gas phase and the hydrogen production rate of the

3 acidogenic reactor, under different HRT values

4 Figure 2: The distribution of the soluble metabolites and the non-consumed carbohydrates during

5 the experimental period of the acidogenic reactor under different HRT values

6 Figure 3 : The percentage of hydrogen in the gas phase and the hydrogen production rate of the

7 acidogenic reactor under different $\mathrm{pH}$ values, when the HRT of the reactor was $12 \mathrm{~h}$.

8 Figure 4. The distribution of the soluble metabolites and the non-consumed carbohydrates

9 during the experimental period of the acidogenic reactor under different $\mathrm{pH}$ values, when the

10 HRT of the reactor was $12 \mathrm{~h}$.

11 Figure 5. Distribution of bacterial families during the operational periods of $3 / 4 \mathrm{BS}, 1 / 3 \mathrm{BS}$ and

$120 \mathrm{BS}$

13 
1 Table 1 The main characteristics of the suspended food industry waste (SFIW) used as feed of 2 the hydrogenogenic reactor

\begin{tabular}{cc}
\hline Characteristic & Value \\
\hline $\mathrm{pH}$ & $11.61 \pm 0.44$ \\
$\mathrm{TSS}(\mathrm{g} / \mathrm{L})$ & $13.40 \pm 1.05$ \\
VSS $(\mathrm{g} / \mathrm{L})$ & $10.80 \pm 0.42$ \\
Total carbohydrates $(\mathrm{g} / \mathrm{L})$ & $12.43 \pm 0.73$ \\
Soluble carbohydrates $(\mathrm{g} / \mathrm{L})$ & $7.94 \pm 0.35$ \\
Total COD $(\mathrm{g} / \mathrm{L})$ & $21.30 \pm 4.07$ \\
Soluble COD $(\mathrm{g} / \mathrm{L})$ & $12.85 \pm 1.90$ \\
\hline
\end{tabular}

3

4

5

6

7

8

9

10

11

12 
Table 2 The effect of the HRT on the main characteristics of the four steady states of the hydrogen- producing reactor

\begin{tabular}{|c|c|c|c|c|}
\hline & HRT $=12 \mathrm{~h}$ & HRT $=8$ h & HRT $=6 \mathrm{~h}$ & HRT $=4 \mathrm{~h}$ \\
\hline $\mathrm{pH}$ & $5.72 \pm 0.07$ & $5.68 \pm 0.05$ & $5.46 \pm 0.08$ & $5.48 \pm 0.07$ \\
\hline TSS $(g / L)$ & $7.82 \pm 0.40$ & $6.45 \pm 0.28$ & $6.61 \pm 0.25$ & $7.88 \pm 0.54$ \\
\hline VSS (g/L) & $6.72 \pm 0.45$ & $5.34 \pm 0.18$ & $5.45 \pm 0.11$ & $6.60 \pm 0.42$ \\
\hline Content in hydrogen $(\%)$ & $52.43 \pm 1.03$ & $50.95 \pm 0.75$ & $55.70 \pm 1.34$ & $61.47 \pm 1.06$ \\
\hline $\mathrm{L} \mathrm{H}_{2} / \mathrm{d}$ & $1.65 \pm 0.06$ & $2.25 \pm 0.06$ & $3.49 \pm 0.13$ & $4.32 \pm 0.08$ \\
\hline $\mathrm{L}$ biogas/d & $3.15 \pm 0.10$ & $4.42 \pm 0.16$ & $6.26 \pm 0.11$ & $7.03 \pm 0.15$ \\
\hline $\mathrm{L}_{2} / \mathrm{L}$ reactor$/ \mathrm{d}$ & $4.13 \pm 0.14$ & 0.15 & $8.72 \pm 0.32$ & $10.79 \pm 0.21$ \\
\hline $\mathrm{L} \mathrm{H}_{2} / \mathrm{kg}$ FIW & $96.27 \pm 3.36$ & $87.60 \pm 2.40$ & $101.75 \pm 3.71$ & $83.94 \pm 1.63$ \\
\hline $\mathrm{mol} \mathrm{H}_{2} /$ mol carbohydrates consumed $*$ & & $1.61 \pm 0.12$ & $2.19 \pm 0.0 .8$ & $2.47 \pm 0.05$ \\
\hline Soluble carbohydrates $(\mathrm{g} / \mathrm{L})$ & $0.26 \pm 0.0$ & $0.39 \pm 0.12$ & $1.07 \pm 0.34$ & $3.13 \pm 0.35$ \\
\hline Total carbohydrates $(\mathrm{g} / \mathrm{L})$ & $1.62 \pm 0.02$ & $2.12 \pm 0.15$ & $3.10 \pm 0.21$ & $4.80 \pm 0.23$ \\
\hline Acetic acid (g/L) & 12 & $2.00 \pm 0.17$ & $1.83 \pm 0.10$ & $1.57 \pm 0.05$ \\
\hline Butyric acid (g/L) & & $4.71 \pm 0.19$ & $3.46 \pm 0.16$ & $2.45 \pm 0.05$ \\
\hline Propionic acid (g/L) & $0.63 \pm 0.08$ & $0.50 \pm 0.05$ & $0.26 \pm 0.08$ & $0.07 \pm 0.00$ \\
\hline Lactic acid (g/L) & - & $0.77 \pm 0.20$ & $2.89 \pm 0.36$ & $3.03 \pm 0.14$ \\
\hline
\end{tabular}




\begin{tabular}{llll}
\hline Soluble COD $(\mathrm{g} / \mathrm{L})$ & $15.59 \pm 0.69$ & $17.10 \pm 0.30$ & $15.60 \pm 0.48$ \\
\end{tabular}

$*_{\text {is referred to the total carbohydrates consumed }}$ 
Table 3 The hydrogen production rates which were calculated based on the reactions (2) - (4) and based on reaction (3), respectively compared with the experimentally measured hydrogen production rates, at each steady state, under different HRT values.

Hydrogen production rates $(\mathrm{mmol} / \mathrm{d})$

\begin{tabular}{|c|c|c|c|}
\hline & $\begin{array}{l}\text { Theoretical taking into } \\
\text { account reactions (2)-(4) }\end{array}$ & $\begin{array}{c}\text { Theoretical taking into account } \\
\text { reaction (3) }\end{array}$ & Experimentally measured \\
\hline HRT $=12 h$ & $138.71 \pm 4.24$ & $65.02 \pm 3.77$ & $67.50 \pm 2.35$ \\
\hline $\mathrm{HRT}=\mathbf{8} \mathrm{h}$ & $193.38 \pm 20.21$ & $122.26 \pm 18.27$ & $93.08 \pm 3.55$ \\
\hline HRT $=6 \mathrm{~h}$ & $217.56 \pm 9.51$ & $125.74 \pm 5.83$ & $142.89 \pm 6.36$ \\
\hline HRT $=4 \mathrm{~h}$ & $256.82 \pm 5.86$ & $133.69 \pm 2.64$ & $176.58 \pm 3.43$ \\
\hline
\end{tabular}


Table 4 The effect of the buffer solution concentration on the main characteristics of the six steady states of the hydrogen- producing reactor

\begin{tabular}{|c|c|c|c|c|c|c|}
\hline & BS & 3/4BS & $1 / 2 \mathrm{BS}$ & $1 / 3 \mathrm{BS}$ & 1/4BS & O BS \\
\hline $\mathrm{pH}$ & $5.91 \pm 0.07$ & $5.55 \pm 0.02$ & $5.40 \pm 0.05$ & $5.32 \pm 0.11$ & $5.31 \pm 0.04$ & $5.00 \pm 0.32$ \\
\hline TSS $(\mathrm{g} / \mathrm{L})$ & $5.70 \pm 0.35$ & $5.16 \pm 0.11$ & $5.66 \pm 0.06$ & $5.84 \pm 0.15$ & $5.81 \pm 0.47$ & $5.81 \pm 0.50$ \\
\hline $\operatorname{VSS}(\mathrm{g} / \mathrm{L})$ & $4.86 \pm 0.37$ & $4.54 \pm 0.10$ & $5.21 \pm 0.0$ & $5.48 \pm 0.20$ & $5.51 \pm 0.39$ & $5.71 \pm 0.50$ \\
\hline Content in hydrogen $(\%)$ & $52.93 \pm 1.82$ & $53.34 \pm 0.86$ & $54.00 \pm 0.69$ & $49.76 \pm 1.19$ & $47.66 \pm 0.56$ & $45.69 \pm 2.67$ \\
\hline $\mathrm{L} \mathrm{H}_{2} / \mathrm{d}$ & $1.66 \pm 0.04$ & $2.38 \pm 0.04$ & $2.43 \pm 0.06$ & $1.60 \pm 0.04$ & $1.53 \pm 0.05$ & $1.47 \pm 0.03$ \\
\hline L biogas/d & $3.13 \pm 0.10$ & $4.46 \pm 0.08$ & $4.49 \pm 0.10$ & $3.22 \pm 0.03$ & $3.21 \pm 0.09$ & $3.24 \pm 0.13$ \\
\hline $\mathrm{L} \mathrm{H}_{2} / \mathrm{L}$ reactor/d & $4.14 \pm 0.10$ & $5.95 \pm 0.10$ & $6.06 \pm 0.16$ & $4.00 \pm 0.10$ & $3.82 \pm 0.11$ & $3.68 \pm 0.08$ \\
\hline $\mathrm{L} \mathrm{H}_{2} / \mathrm{kg}$ FIW & $96.57 \pm 2.39$ & 1 & $141.47 \pm 3.64$ & $93.37 \pm 2.39$ & $89.23 \pm 2.65$ & $85.90 \pm 1.82$ \\
\hline $\mathrm{mol} \mathrm{H}_{2} /$ mol carbohydrates * & $1.59 \pm 0.12$ & $2.37 \pm 0.09$ & $3.30 \pm 0.15$ & $2.07 \pm 0.14$ & $2.01 \pm 0.08$ & $3.73 \pm 0.20$ \\
\hline Soluble carbohydrates $(\mathrm{g} / \mathrm{L})$ & $0.59 \pm 0.36$ & $1.28 \pm 0.22$ & $2.62 \pm 0.21$ & $2.89 \pm 0.76$ & $2.32 \pm 0.25$ & $3.87 \pm 2.13$ \\
\hline Total carbohydrates $(\mathrm{g} / \mathrm{L})$ & $1.62 \pm 0.10$ & \pm 0.11 & $4.78 \pm 0.15$ & $4.39 \pm 0.14$ & $4.50 \pm 0.07$ & $8.32 \pm 0.12$ \\
\hline Acetic acid (g/L) & $2.65 \pm 0.30$ & $1.90 \pm 0.20$ & $1.61 \pm 0.06$ & $1.63 \pm 0.08$ & $1.51 \pm 0.10$ & $1.66 \pm 0.40$ \\
\hline Butyric acid (g/L) & $3.13 \pm 0.69$ & $4.15 \pm 0.19$ & $4.89 \pm 0.18$ & $3.83 \pm 0.18$ & $3.68 \pm 0.24$ & $2.49 \pm 0.17$ \\
\hline
\end{tabular}




\begin{tabular}{ccccccc}
\hline Propionic acid $(\mathrm{g} / \mathrm{L})$ & $0.67 \pm 0.20$ & $0.58 \pm 0.07$ & $0.25 \pm 0.04$ & $0.11 \pm 0.00$ & $0.13 \pm 0.02$ \\
Lactic acid $(\mathrm{g} / \mathrm{L})$ & $0.02 \pm 0.00$ & $0.03 \pm 0.02$ & $0.00 \pm 0.00$ & $0.01 \pm 0.00$ & $0.34 \pm 0.12$ & $0.16 \pm 0.08$ \\
Soluble COD $(\mathrm{g} / \mathrm{L})$ & $16.87 \pm 0.46$ & $16.94 \pm 0.10$ & $16.20 \pm 0.29$ & $16.67 \pm 0.48$ & $14.44 \pm 0.88$ & $14.70 \pm 0.27$ \\
\hline
\end{tabular}

*is referred to the total carbohydrates consumed 
Table 5 The hydrogen production rates which were calculated based on the reactions (2) - (4) and based on reaction (3), respectively compared with the experimentally measured hydrogen production rates, at each steady state, under different $\mathrm{pH}$ values.

\section{Hydrogen production rates $(\mathrm{mmol} / \mathrm{d})$}

\begin{tabular}{|c|c|c|c|}
\hline & $\begin{array}{l}\text { Theoretical taking into } \\
\text { account reactions (2)-(4) }\end{array}$ & $\begin{array}{l}\text { Theoretical taking into } \\
\text { account reaction (3) }\end{array}$ & Experimentally measured \\
\hline BS & $120.34 \pm 18.65$ & $56.90 \pm 12.53$ & $67.71 \pm 1.68$ \\
\hline 3/4BS & $133.35 \pm 3.46$ & $88.92 \pm 3.21$ & $97.34 \pm 1.57$ \\
\hline $1 / 2 \mathrm{BS}$ & $115.72 \pm 4.89$ & $75.41 \pm 3.40$ & $99.19 \pm 2.56$ \\
\hline 1/3 BS & $111.92 \pm 5.45$ & $69.68 \pm 3.26$ & $66.47 \pm 1.68$ \\
\hline 1/4 BS & $105.76 \pm 6.23$ & $66.93 \pm 4.38$ & $62.57 \pm 1.86$ \\
\hline 0 BS & $83.34 \pm 9.46$ & $44.02 \pm 3.48$ & $60.23 \pm 1.28$ \\
\hline
\end{tabular}




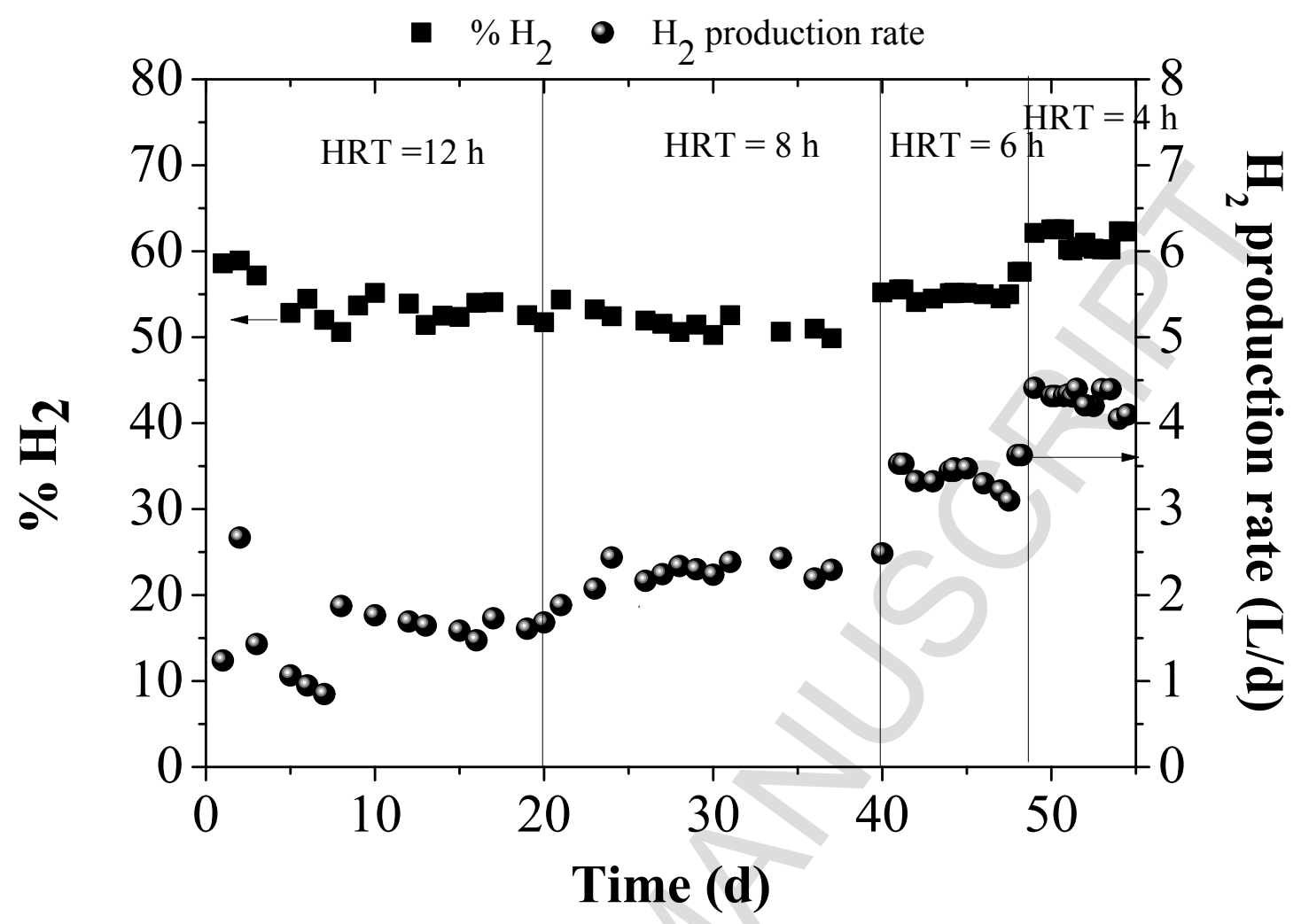

Figure 1 : The percentage of hydrogen in the gas phase and the hydrogen production rate of the acidogenic reactor, under different HRT values 


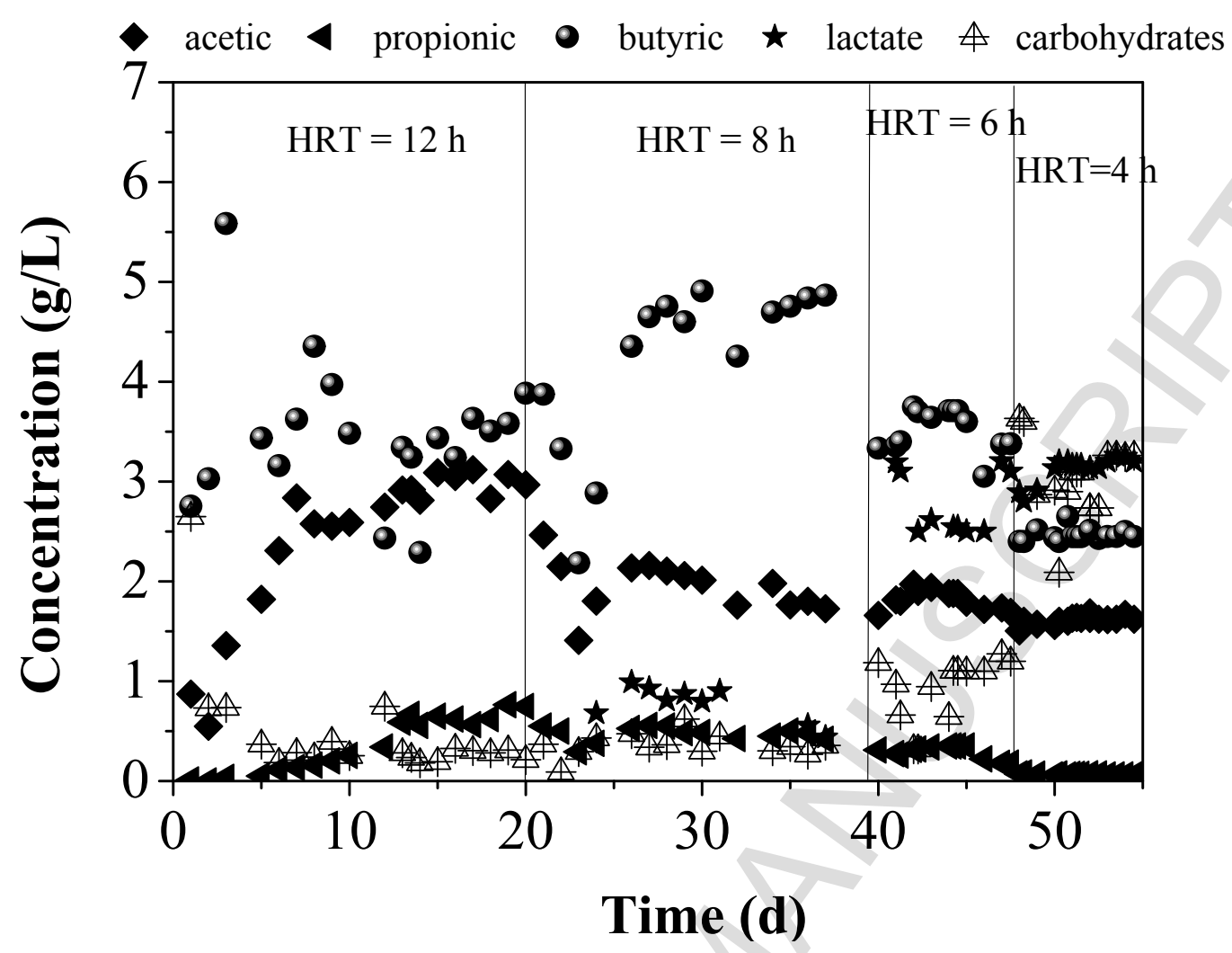

Figure 2: The distribution of the soluble metabolites and the non-consumed carbohydrates during the experimental period of the acidogenic reactor under different HRT values 


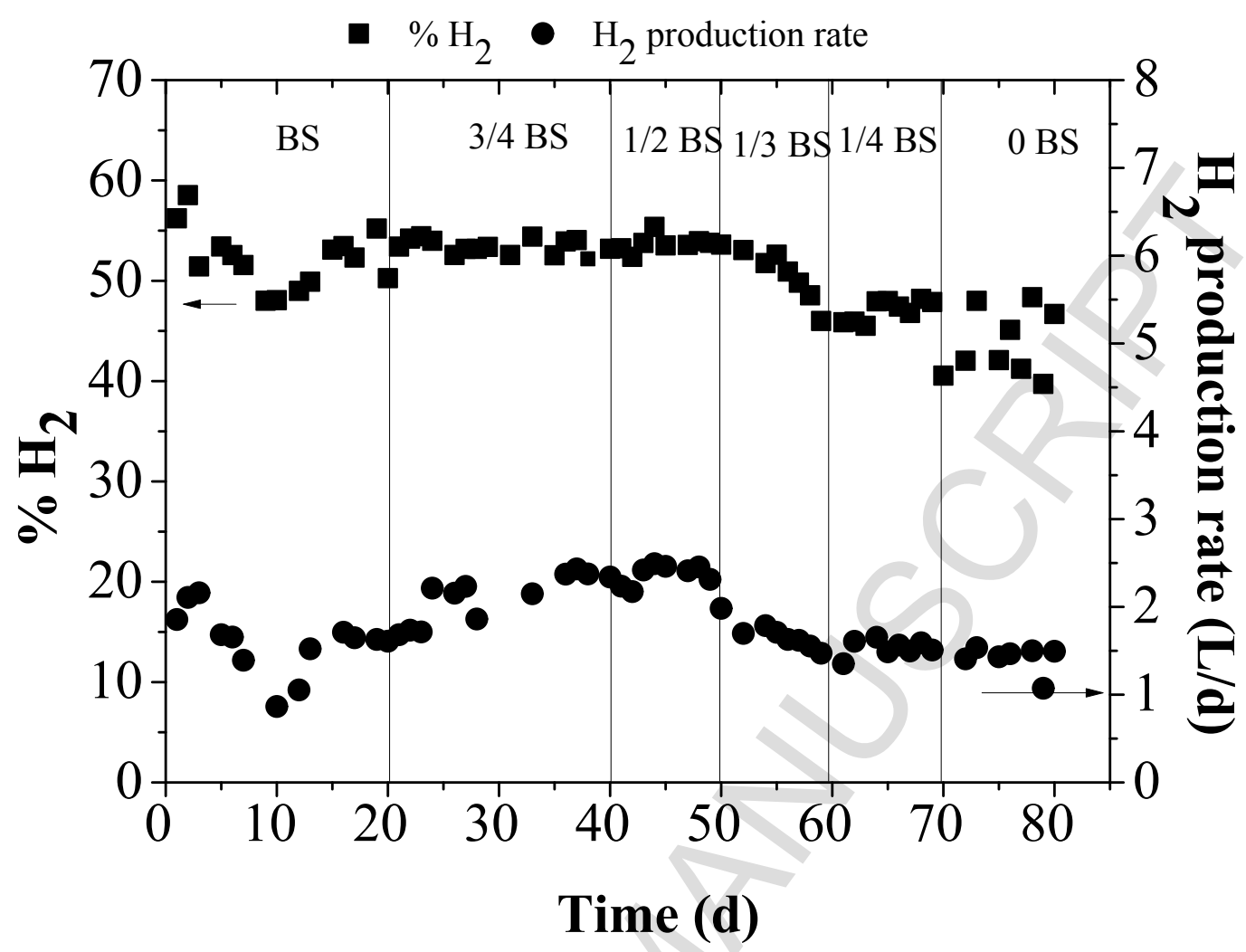

Figure 3: The percentage of hydrogen in the gas phase and the hydrogen production rate of the acidogenic reactor under different $\mathrm{pH}$ values, when the HRT of the reactor was $12 \mathrm{~h}$. 


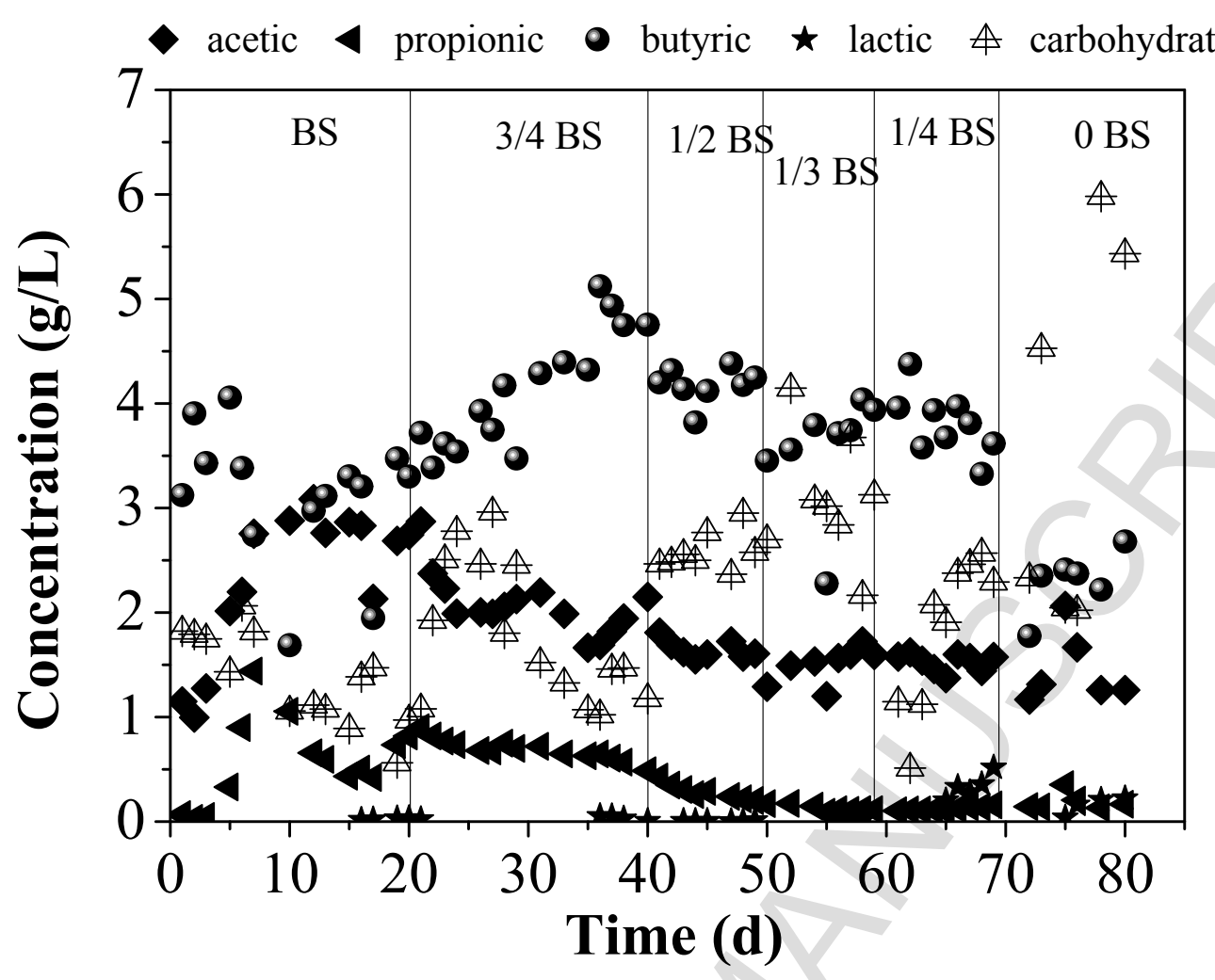

Figure 4. The distribution of the soluble metabolites and the non-consumed carbohydrates during the experimental period of the acidogenic reactor under different $\mathrm{pH}$ values, when the HRT of the reactor was $12 \mathrm{~h}$. 


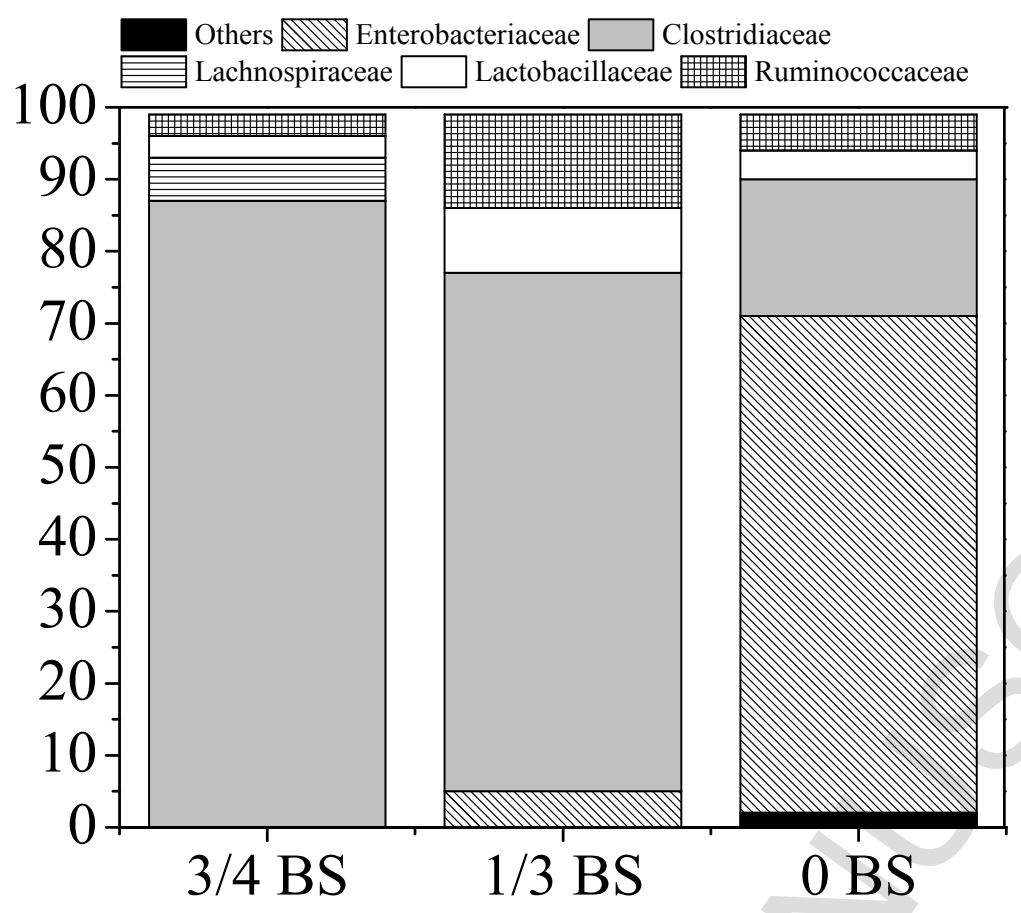

Figure 5. Distribution of bacterial families during the operational periods of $3 / 4 \mathrm{BS}, 1 / 3 \mathrm{BS}$ and 0 BS 